\title{
Numerical Investigation of Injection Timing Influence on Fuel Slip and Influence of Compression Ratio on Knock Occurrence in Conventional Dual Fuel Engine
}

\author{
Mario Sremec $^{* 1}$, Ivan Taritaš ${ }^{2}$, Momir Sjeric ${ }^{3}$, Darko Kozarac ${ }^{4}$ \\ ${ }^{1}$ Department of Internal Combustion Engines and Motor Vehicles, Faculty of Mechanical Engineering and \\ Naval Architecture, University of Zagreb, Ivana Lučića 5, Zagreb, Croatia \\ e-mail: mario.sremec@fsb.hr \\ ${ }^{2}$ Department of Internal Combustion Engines and Motor Vehicles, Faculty of Mechanical Engineering and \\ Naval Architecture, University of Zagreb, Ivana Lučića 5, Zagreb, Croatia \\ e-mail: ivan.taritas@fsb.hr \\ ${ }^{3}$ Department of Internal Combustion Engines and Motor Vehicles, Faculty of Mechanical Engineering and \\ Naval Architecture, University of Zagreb, Ivana Lučića 5, Zagreb, Croatia \\ e-mail: momir.sjeric@fsb.hr \\ ${ }^{4}$ Department of Internal Combustion Engines and Motor Vehicles, Faculty of Mechanical Engineering and \\ Naval Architecture, University of Zagreb, Ivana Lučića 5, Zagreb, Croatia \\ e-mail: darko.kozarac@fsb.hr

\begin{abstract}
Cite as: Sremec, M., Taritaš, I., Sjerić, M., Kozarac, D., Numerical Investigation of Injection Timing Influence on Fue Slip and Influence of Compression Ratio on Knock Occurrence in Conventional Dual Fuel Engine, J. sustain. dev.
\end{abstract} \\ energy water environ. syst., 5(4), pp 518-532, 2017, DOI: http://dx.doi.org/10.13044/j.sdewes.d5.0163
}

\begin{abstract}
Compressed natural gas can be used in diesel engine with great benefits, but because of its low reactivity it is usually used in a so called dual fuel combustion process. Optimal parameters for dual fuel engines are not yet investigated thoroughly which is the motivation for this work. In this work, a numerical study performed in a cycle simulation tool (AVL Boost v2013) on the influence of different injection timings on fuel slip into exhaust and influence of compression ratio on knock phenomena in port injected dual fuel engine was conducted. The introduction of natural gas into the intake port of a diesel engine usually results in some fuel slipping into the exhaust port due to valve overlap. By analysing the simulation results, the injection strategy that significantly decreases the natural gas slip is defined. The knock occurrence study showed that the highest allowed compression ratio that will result in knock free operation of the presented engine is 18 for ambient intake condition, while for charged intake conditions the compression ratio should be lowered to 16 .
\end{abstract}

\section{KEYWORDS}

Diesel engines, Dual fuel, Compressed natural gas, Methane, Injection timing, Fuel slip, Knock.

\section{INTRODUCTION}

Dual fuel combustion has been identified as a combustion mode that has a great potential for implementing alternative fuel (natural gas) and for decreasing harmful exhaust emissions from diesel engines [1]. Dual fuel engines run with natural gas and

\footnotetext{
* Corresponding author
} 
diesel fuel simultaneously. Although Compressed Natural Gas (CNG) is also a fossil fuel, it burns cleaner than other fossil fuels and is usually classified as an alternative fuel [2]. Potential of natural gas in reduction of Carbon dioxide $\left(\mathrm{CO}_{2}\right)$ emission is up to $25 \%$ [2]. Dual fuel combustion also shows some other benefits compared to conventional diesel operation, such as decrease of Nitric oxides $\left(\mathrm{NO}_{\mathrm{x}}\right)$ and Soot emissions [3, 4]. Currently there are two types of dual fuel engines: port injected (conventional) and Directly Injected (HPDI) [3, 4]. A large part of the research is made with diesel engines converted into the port injected (conventional) dual fuel engine $[5,6]$ which has the benefit that it can be propelled as dual fuel (diesel and CNG) and as a mono fuel (only diesel fuel) when only gaseous fuel is used $[1,4]$. The conversion from conventional diesel engine to dual fuel engine operation requires the addition of gas supply system to the intake pipe and modification of the engine control unit. The main disadvantages of dual fuel combustion are a decrease in thermal efficiency and significant increase of the Unburned Hydrocarbons (UHC) and Carbon monoxide (CO) emissions. Authors in [7, 8] show significant increase of UHC emission and increase of $\mathrm{CO}$ emission [9] compared to the normal diesel operation. One of the reasons for increased concentration of UHC emissions is the valve overlap, which leads to fuel slip (port-injected fuel) into the exhaust. In order to achieve better cylinder scavenging, the conventional diesel engine is designed with positive valve overlap. This design is suitable for engines that feature a direct fuel injection system, where the fuel is usually injected at the time when the intake and exhaust valves are closed. Due to this valve overlap, by adding the gas supply system to the intake pipe, some of the gaseous fuel flows out of the cylinder into the exhaust pipe. This phenomenon occurs at all ranges of engine loads and speeds, especially in charged engines because of higher pressure difference between intake and exhaust ducts. The need for optimizing injection strategy in dual fuel operation in terms of both energetic and environmental behaviour has been confirmed by the authors in [10]. Also, the authors in [11] showed that Start Of Injection (SOI) point has a significant influence on the dual fuel combustion process.

In order to prepare the process of conversion of conventional diesel engine into the dual fuel engine in the Laboratory of IC engines and motor vehicles at the Faculty of Mechanical Engineering and Naval Architecture in Zagreb, numerical simulations of the engine were performed. The main objective of these numerical simulations was to find the best injection timing of gaseous fuel into the intake pipe, which will lead to the smallest amount of fuel slipping into the exhaust pipe due to the valve overlap.

The second objective was to determine the maximum allowed Compression Ratio (CR) for knock free dual fuel operation. Since in dual fuel engine a part of the mixture burns with premixed turbulent flame there is a risk of knock occurrence which could result in engine damage. Although natural gas has a high octane rating, the original CR is too high for knock free operation. By using a simulation model the tendency of engine towards knock can be determined for several different CRs which will support a decision regarding the $\mathrm{CR}$ chosen for experimental engine. All simulations were performed with the simulation tool AVL Boost v2013, the software designed for cyclic simulations of entire engine systems with the emphasis on flows through the engine and cylinder combustion.

\section{MODEL DESCRIPTION AND TEST CASES}

The numerical simulation model is based on the existing Hatz diesel engine 1D81 installed in the Laboratory of IC engines and motor vehicles at the Faculty of Mechanical Engineering and Naval Architecture in Zagreb. There is a plan to convert the engine to port injected dual fuel engine which is the reason for using its geometry in this model. The simulation model includes the complete geometry of the experimental setup with entire intake and exhaust system and all additional devices (Figure 1). 


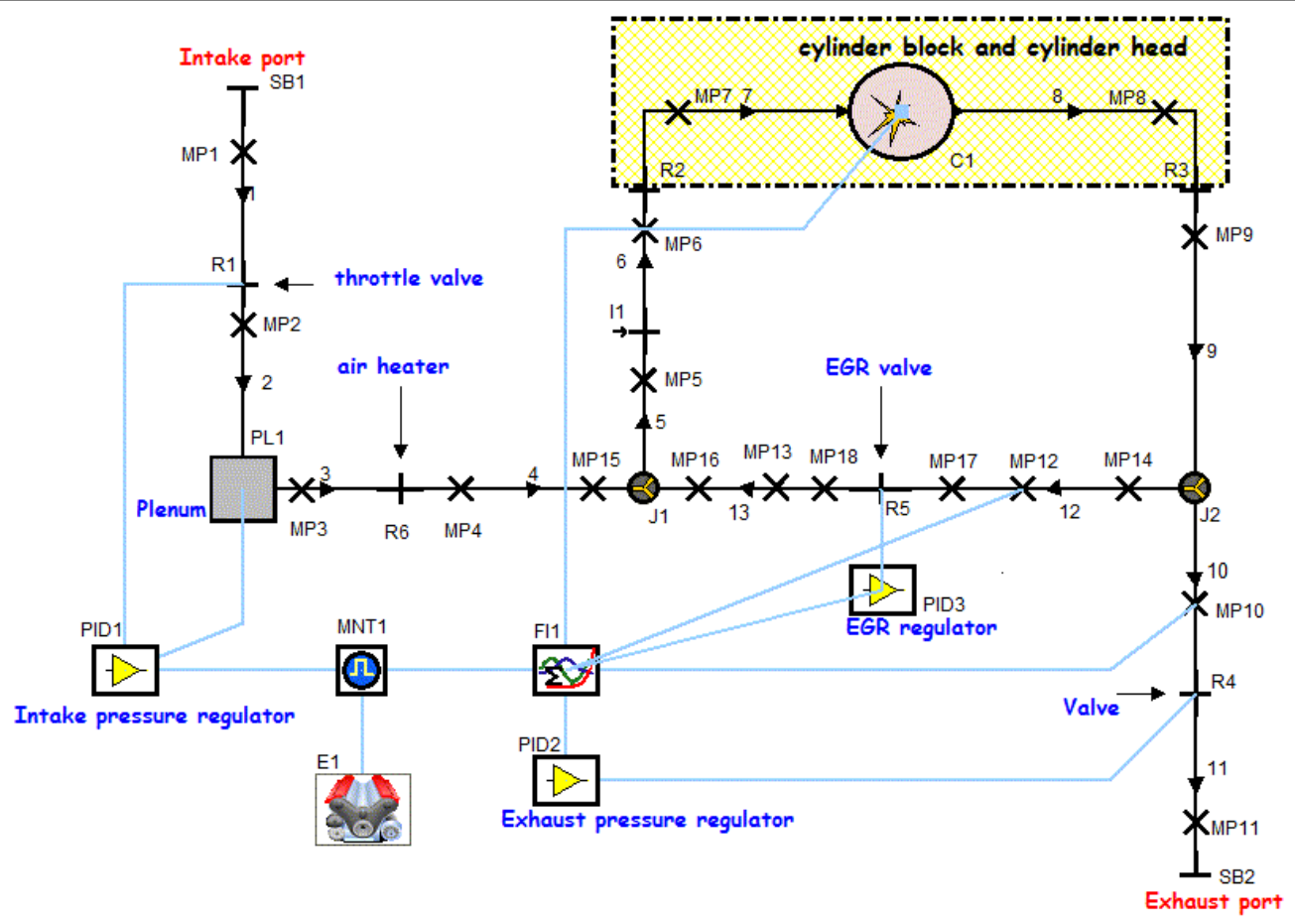

Figure 1. Engine model created in AVL Boost v2013

The numerical model consists of: intake line [from System Boundary 1 (SB1) to Cylinder (C1)], exhaust line [from Cylinder to System Boundary 2 (SB2)] and Exhaust Gas Recirculation (EGR) line. The intake line consists of throttle valve (R1), plenum (PL1), air heater (only flow resistance of the air heater is modelled with single restriction element), fuel injector and junction with the EGR line. The exhaust line consists of valve for pressure regulation and a junction with the EGR line. The PID regulators are placed for fine adjustment of the operating parameters. To appropriately monitor the entire process, a lot of measuring points were placed in the simulation model. The Vibe function with constant parameters in all cases was used to define the rate of heat release. The mixture of methane and diesel fuel with $95 \%$ of methane mole fraction was applied.

The real life injector on our experimental setup is designed as an on/off valve, and it allows very precise control of injected fuel amount through a change of the Injection Duration (ID) at constant fuel pressure. In the case of continuous injection strategy, the fuel injector is constantly open and fuel amount is controlled by changing the fuel pressure.

The analysis of the fuel slip from the cylinder is made by monitoring the fuel amount (kg/cycle) at the intake (measuring point 7 ) end exhaust pipe (measuring point 8 ). In the first step, the effect of continuous port fuel injection on the gaseous fuel slip to the exhaust pipe due to valve overlap is analysed. Table 1 shows the test cases with continuous fuel injection in this analysis. After the calculation with continuous injection strategy was made, intermittent port injection strategy was applied, and the influence of different injection timings (different SOI moments) and different injection durations on gaseous fuel slip to the exhaust was analysed. In the numerical model, SOI is defined through its relative value to the Firing Top Dead Center (FTDC) which is set to $0^{\circ}$ Crank Angle (CA).

The first set of results was obtained for ID of $180^{\circ} \mathrm{CA}$ (Figure 2), while the second set was made for ID of $90^{\circ} \mathrm{CA}$ (Figure 3). After this the final analysis with finer resolution was performed in order to optimize the SOI point. Criteria for determining the optimal SOI point was the least fuel concentration in the exhaust pipe (measuring point 8). Test cases for intermittent injection strategy are given in Table 2. 
Table 1. Test cases with continuous fuel injection

\begin{tabular}{ccccc}
\hline Case name & $n[\mathrm{r} / \mathrm{min}]$ & $p_{\text {intake }}[\mathrm{bar}]$ & Air excess ratio $(\lambda)$ & EGR [\%] \\
\hline 1.1 & 1,000 & & & \\
1.2 & 1,500 & 1 & 1.5 & 0 \\
1.3 & 2,000 & & & \\
1.4 & 3,000 & & & \\
\hline 2.1 & 1,000 & & 1.5 & 0 \\
2.2 & 1,500 & 2.2 & & \\
2.3 & 2,000 & & & \\
2.4 & 3,000 & & & \\
\hline
\end{tabular}

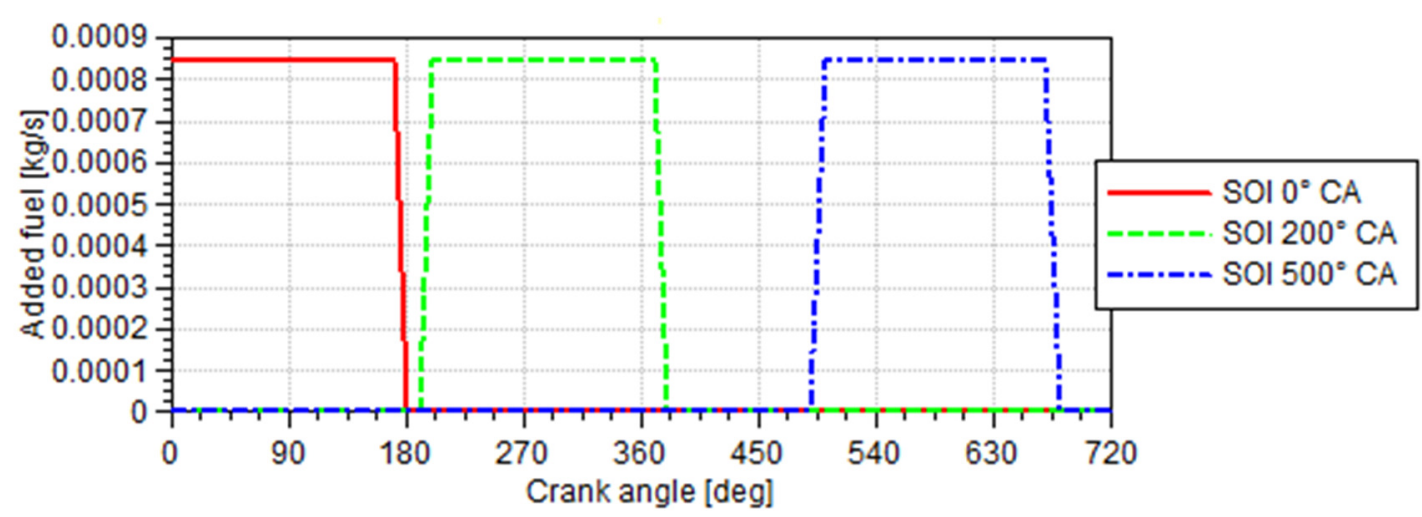

Figure 2. Injection profiles with ID $=180^{\circ} \mathrm{CA}$

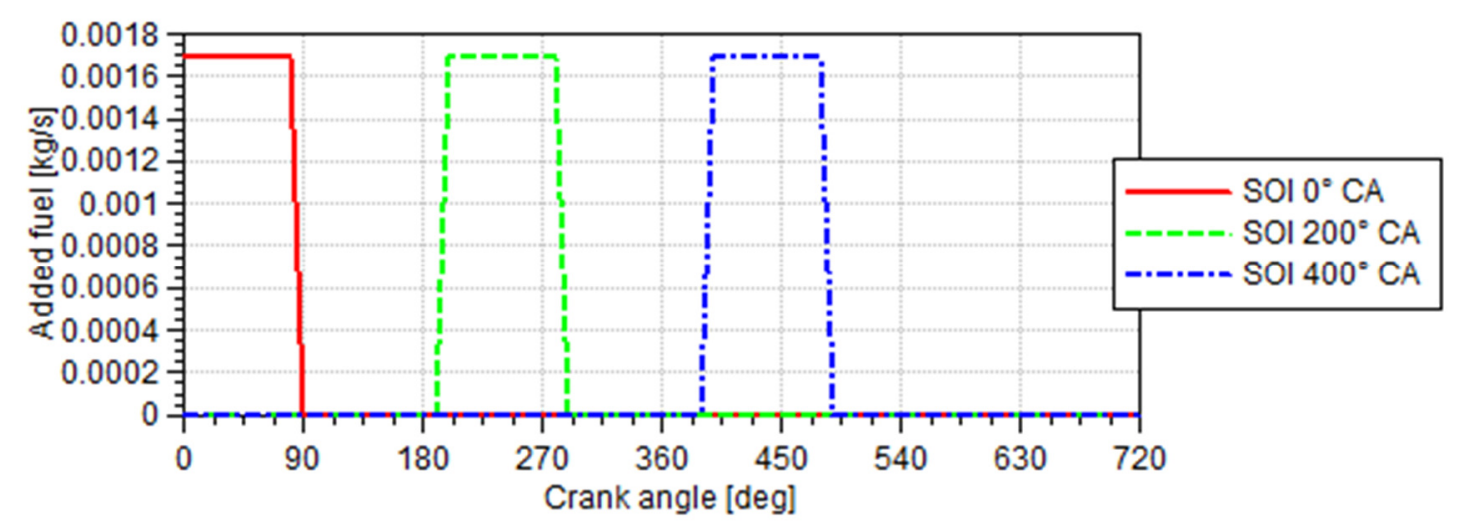

Figure 3. Injection profile with ID $=90^{\circ} \mathrm{CA}$

Table 2. Test cases with intermittent fuel injection

\begin{tabular}{ccccccc}
\hline $\begin{array}{c}\text { Case } \\
\text { name }\end{array}$ & $\begin{array}{c}n \\
{[\mathrm{r} / \mathrm{min}]}\end{array}$ & $\begin{array}{c}p_{\text {intake }} \\
{[\mathrm{bar}]}\end{array}$ & Air excess ratio $(\lambda)$ & EGR [\%] & ID [ $\left.{ }^{\circ} \mathrm{CA}\right]$ & $\begin{array}{c}\text { SOI relative to } \\
\text { FTDC }\left[{ }^{\circ} \mathrm{CA}\right]\end{array}$ \\
\hline 3.1 & 1,000 & & & & & \\
3.2 & 1,500 & 1 & 1.5 & 0 & 90,180 & $0,100,200$, \\
3.3 & 2,000 & 1 & & & & $300,400,500$ \\
3.4 & 3,000 & & & & & \\
\hline 4.1 & 1,000 & & 1.5 & 0 & 90,180 & $0,100,200$, \\
4.2 & 1,500 & 2.2 & & & & $300,400,500$ \\
4.3 & 2,000 & & & & & \\
4.4 & 3,000 & & & & & \\
\hline
\end{tabular}


The second objective of this study was to find the CR which allows knock free dual fuel operation in all conditions. Test cases that were analysed in this part of the study are given in Table 3. As can be seen, the knock analysis was also performed for all three engine speeds, both intake pressure levels and at 5 different levels of CR. The CR range is from 16 to 20.5, as this is the CR of the original Hatz 1D81Z diesel engine. In the knock analysis the newly developed model for prediction of knock [12] was used to determine the knock onset and knock intensity. In this part of the study a two-zone combustion simulation approach was used, where the in-cylinder content is divided into burned and unburned zones. The rate of heat release was calculated using Vibe function, while for the calculation of knock ignition delay tables for methane [13] were applied. The parameters of knock model are used according to experience acquired in [14].

Table 3. Test cases for knock analysis

\begin{tabular}{ccccccc}
\hline $\begin{array}{c}\text { Case } \\
\text { name }\end{array}$ & $\begin{array}{c}n \\
{[\mathrm{r} / \mathrm{min}]}\end{array}$ & $\begin{array}{c}p_{\text {intake }}[\mathrm{bar}] \\
\text { ratio }(\lambda)\end{array}$ & $\begin{array}{c}\text { Air excess } \\
{[\%]}\end{array}$ & $\begin{array}{c}\text { Combustion } \\
\text { duration } \\
{\left[{ }^{\circ} \mathrm{CA}\right]}\end{array}$ & $\mathrm{CR}$ \\
\hline 5.1 & 1,000 & 1 & 1.5 & 0 & 60 & $20.5,19,18,17,16$ \\
5.2 & 2,000 & 2.2 & 1.0 & & 30 & \\
5.3 & 3,000 & 2.00 & & & & \\
\hline
\end{tabular}

\section{RESULTS AND DISCUSSIONS}

It was mentioned that the measure for monitoring the fuel slip is the mass of fuel in the exhaust port (MP8). Instead of using the exact value of mass concentration, the relative value of fuel slip was calculated by dividing the exhaust fuel concentration and the intake fuel concentration:

$$
\text { Fuel slip }=\frac{\text { Fuel concentration }(\mathrm{MP} 8)}{\text { Fuel concentration }(\mathrm{MP7})} \times 100[\%]
$$

Figure 4 shows the fuel slip dependence on engine speed and intake pressure for continuous injection. Full line shows the results for the intake pressure of 1 bar while the dashed line shows results for the intake pressure of 2.2 bar. It is important to keep in mind that the simulations were performed only at four different speeds. Therefore the straight lines between them are not representative.

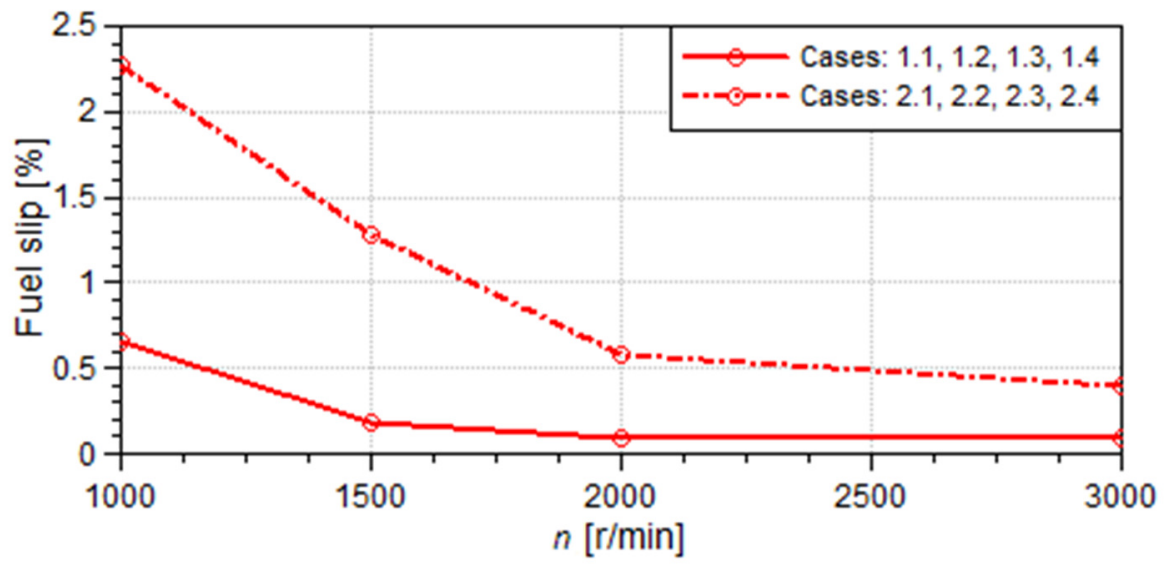

Figure 4. Fuel slip through exhaust valve for continuous injection 
It can be observed that at lower engine speed the fuel slip is more pronounced, while at the high engine speed it is very low. As can be seen in Figure 4, at 1,000 r/min fuel slip is $0.6 \%$ at naturally aspirated condition and $2.3 \%$ at charged condition. Thus, higher intake pressure leads to higher fuel slip level.

The results of the initial simulations with intermittent injection strategy, for different SOI values, $\mathrm{ID}=180^{\circ} \mathrm{CA}$ and $p_{\text {intake }}=1 \mathrm{bar}$ are shown in Figure 5 . On the same figure the corresponding result of the case with continuous injection is also shown.

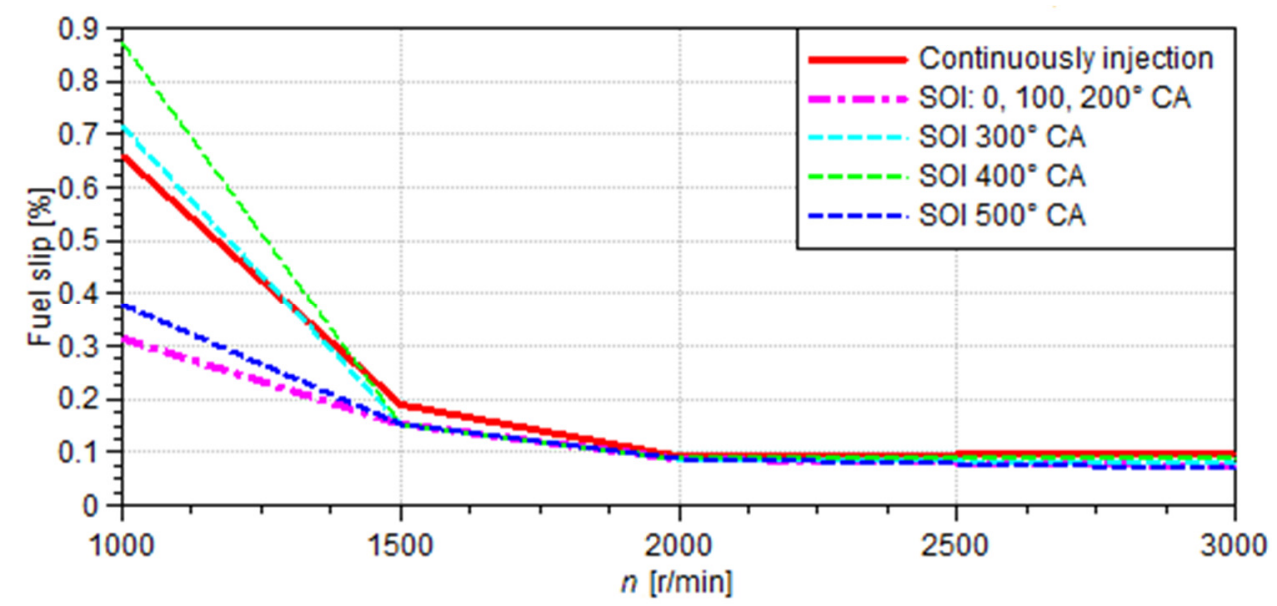

Figure 5. Fuel slip through exhaust valve at ambient intake pressure for different injection timings $\left(\mathrm{ID}=180^{\circ} \mathrm{CA}\right)$

The results show that cases with $\mathrm{SOI}=0,100$ and $200^{\circ} \mathrm{CA}$ have very similar results and that the fuel slip in these cases is the lowest. The cases with SOI $=300$ and $400^{\circ} \mathrm{CA}$ give even worse results than the case with continuous injection. The difference between different injection timings is only observed at 1,000 r/min points, while at higher engine speeds the differences can be neglected.

The results of different injection timings but now with shorter ID (ID $=90^{\circ} \mathrm{CA}$ ) are shown in Figure 6. With a shorter ID the case with $\mathrm{SOI}=300^{\circ} \mathrm{CA}$ becomes similar to the cases $\mathrm{SOI}=0,100$ and $200^{\circ} \mathrm{CA}$, while at the case with $\mathrm{SOI}=400^{\circ} \mathrm{CA}$ the fuel slip slightly increases, compared to ID $=180^{\circ} \mathrm{CA}$.

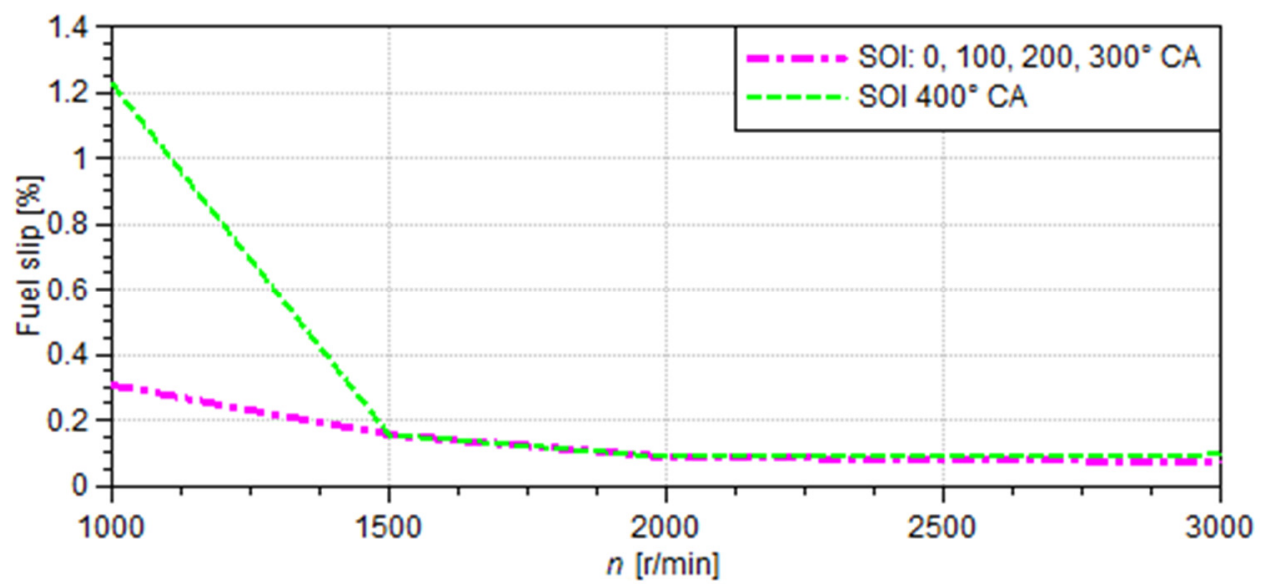

Figure 6. Fuel slip through exhaust valve at ambient intake pressure for different injection points $\left(\mathrm{ID}=90^{\circ} \mathrm{CA}\right)$

Similar behaviour is obtained in charged conditions with $p_{\text {intake }}=2.2$ bar with the difference only in number values. Figure 7 shows the result for ID $=180^{\circ} \mathrm{CA}$ and the 
same trend as in the case with ambient conditions can be noticed. The cases with SOI 0 , 100 and $200^{\circ} \mathrm{CA}$ are almost the same. When the ID is lowered to $90^{\circ} \mathrm{CA}$ the case with $\mathrm{SOI}=300^{\circ} \mathrm{CA}$ becomes equal to cases with $\mathrm{SOI}=0,100$ and $200^{\circ} \mathrm{CA}$, as was the case at ambient conditions. This leads to the conclusion that SOI is not most important for minimizing fuel slip and that the End of Injection (EOI) has more influence on total fuel slip.

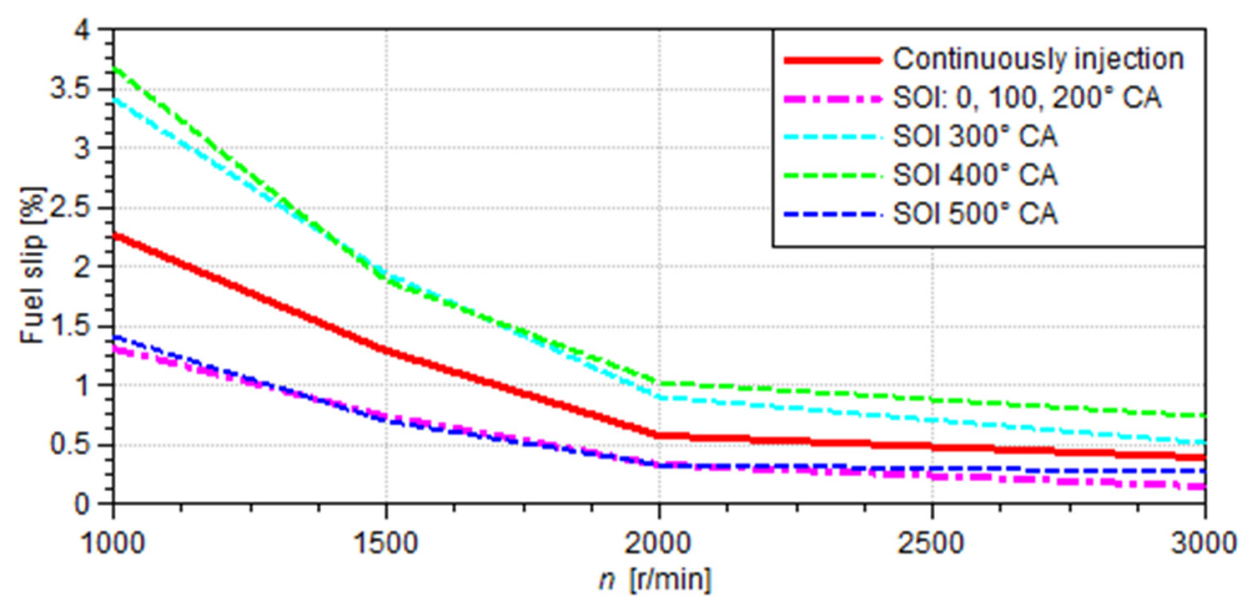

Figure 7. Fuel slip through exhaust valve at charged engine conditions $\left(p_{\text {intake }}=2.2\right.$ bar $)$ for different $\mathrm{SOI}\left(\mathrm{ID}=180^{\circ} \mathrm{CA}\right)$

In the case where the $\mathrm{SOI}=300^{\circ} \mathrm{CA}$ and $\mathrm{ID}=90^{\circ} \mathrm{CA}$, the $\mathrm{EOI}=390^{\circ} \mathrm{CA}$, which is similar to $\mathrm{SOI}=200^{\circ} \mathrm{CA}$ and $\mathrm{ID}=180^{\circ} \mathrm{CA}$, the results lead to the conclusion that $\mathrm{EOI}$ should not be retarded further than some critical point after which fuel slip increases. Refining the results on Figure 8 shows that the $\mathrm{SOI}=320^{\circ} \mathrm{CA}$ is the latest point for SOI with ID of $90{ }^{\circ} \mathrm{CA}$. Later injections (SOI $=340^{\circ} \mathrm{CA}$ or later) result in increasing of the fuel slip to exhaust pipe. This means that the critical point for EOI is around $410^{\circ} \mathrm{CA}$.

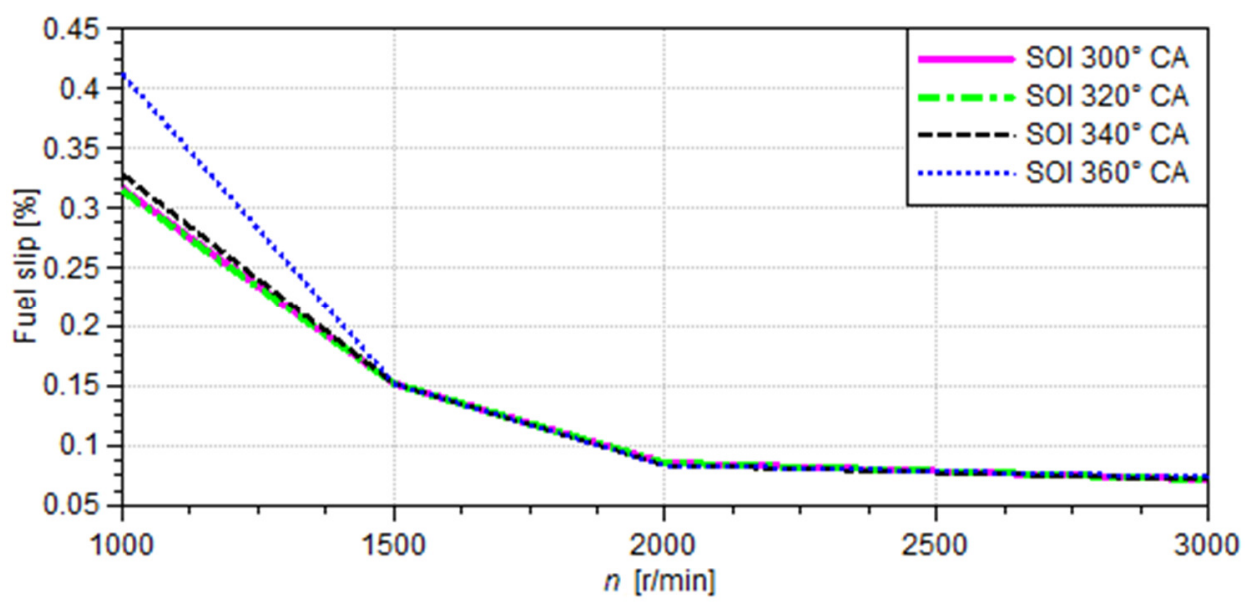

Figure 8 . Fuel slip for $\mathrm{SOI} 300^{\circ} \mathrm{CA}$ to $360^{\circ} \mathrm{CA}\left(\mathrm{ID}=90^{\circ} \mathrm{CA}\right)$

The test with ID of $180^{\circ} \mathrm{CA}$ (Figure 9) confirms the value of critical point for EOI, since the results with $\mathrm{SOI}=240^{\circ} \mathrm{CA}$ (black line) is higher than for $\mathrm{SOI}=200$ or $220^{\circ} \mathrm{CA}$ which means that the increase of fuel slip starts once EOI becomes larger than $400^{\circ} \mathrm{CA}$. Finally, the appropriate injection timing can result in the reduction of the fuel slip up to $33 \%$ compared to the case with continuous injection, while inappropriate injection timing can result with the increase of fuel slip up to $62 \%$ in charged condition. Also, a lower fuel slip implies a higher thermal efficiency. 


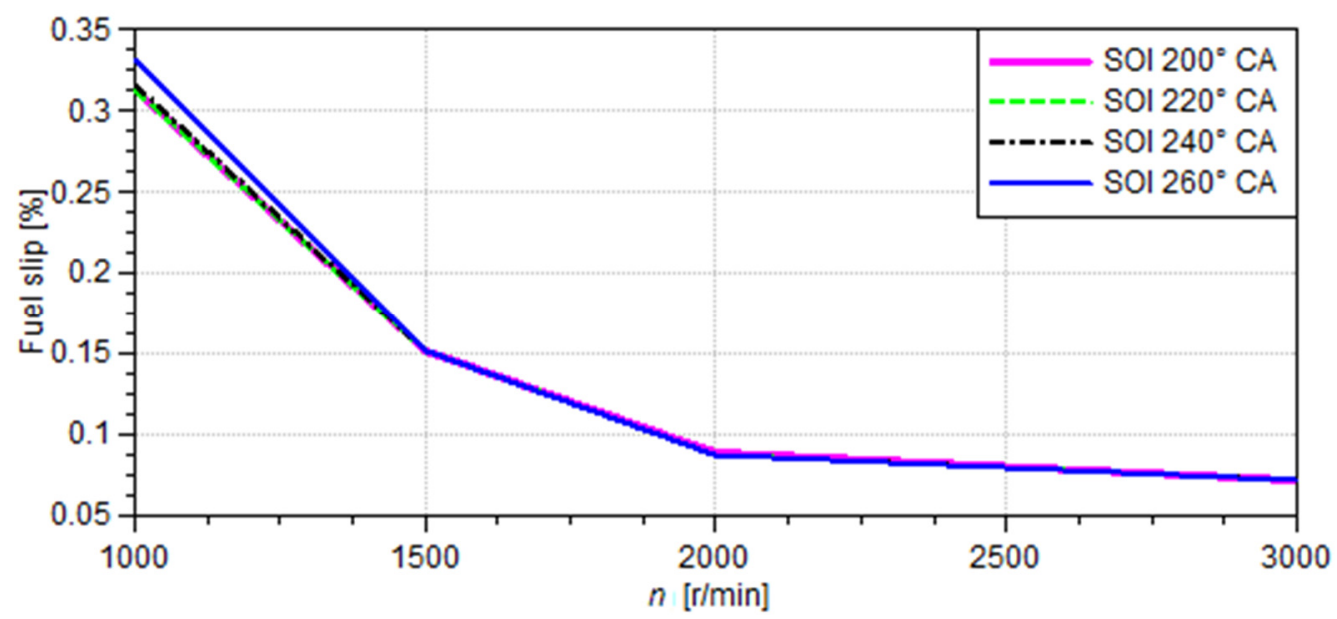

Figure 9. Fuel slip for SOI $200^{\circ} \mathrm{CA}$ to $260^{\circ} \mathrm{CA}\left(\mathrm{ID}=180^{\circ} \mathrm{CA}\right)$

The results of the simulation also reveal the cause of the fuel slip into the exhaust pipe. The major source of the fuel slip into the exhaust pipe is the fuel that is retained in the intake pipe, close to the intake valve, after the intake valve closes. This fuel waits for the intake process of the next cycle, and during the valve overlap some of it slips into the exhaust. Figure 10 shows the fuel concentration close to the intake valve during one cycle for several injection timings.

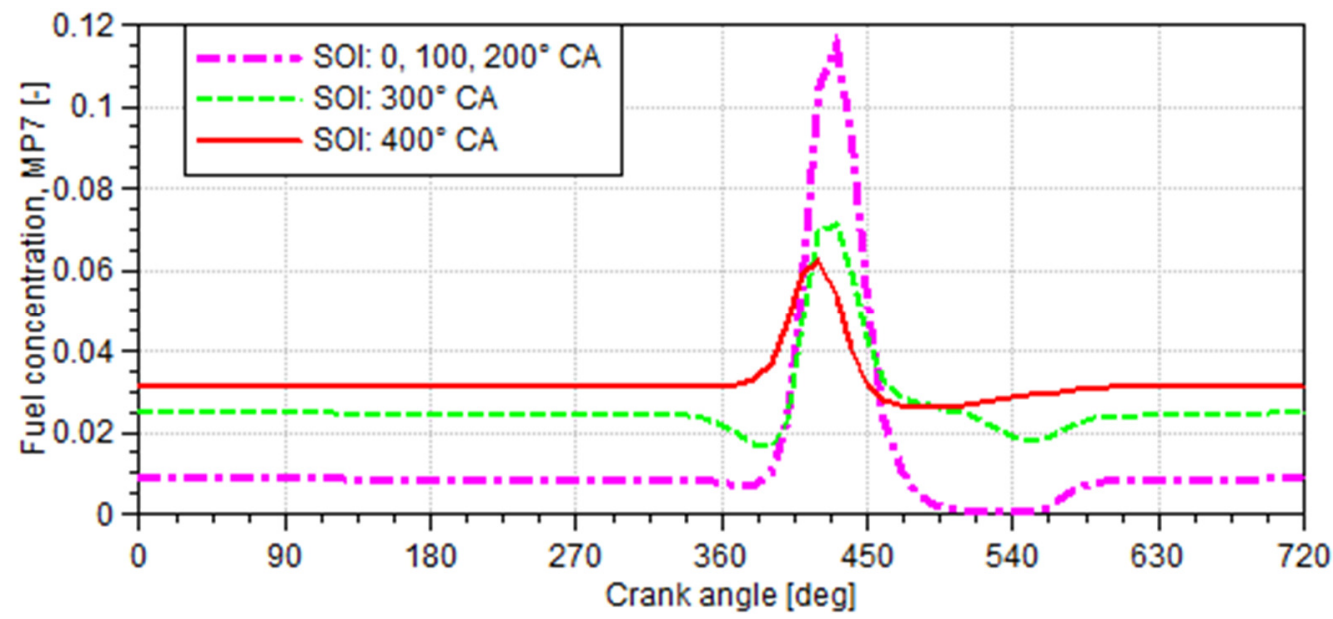

Figure 10. Dependence of fuel concentration in intake pipe on CA $\left(p_{\text {intake }}=1 \mathrm{bar}, \mathrm{ID}=180{ }^{\circ} \mathrm{CA}\right.$, engine speed $=1,000 \mathrm{r} / \mathrm{min}$ )

It can be seen that even though the cases with $\mathrm{SOI}=0,100$ and $200^{\circ} \mathrm{CA}$ have different injection profiles, the fuel concentration at intake valve changes much later (around $400^{\circ} \mathrm{CA}$ ). This is caused by the fact that only then the flow through the intake system brings the fuel from the injection point, which is $100 \mathrm{~mm}$ from intake valve, to the intake valve. If the injection is too late $\left(\mathrm{SOI}=300\right.$ or $400^{\circ} \mathrm{CA}$ ) all the injected fuel does not come into the cylinder and waits in front of the valve for the next cycle. This fuel that is located in front of the intake valve is the fuel that can slip to the exhaust during valve overlap. In the cases with early injection the small concentration of fuel that is increased at the end of intake stroke is caused by the backflow of charge from cylinder to the intake pipe, caused by late intake valve closing.

The analysis of the results showed that the injection timing has an influence on fuel slip from cylinder due to the valve overlap. The most important parameter for determining the optimum injection timing is the EOI. The results for different injection 
timings obtained in this research are valid only for simulated engine and for the intake system geometry (location of fuel injector on intake pipe) that has been defined in this research.

\section{Knock}

To fulfil the second objective, the calculation with two-zone Vibe model and integrated knock calculation was used [12]. The original engine is uncharged and has CR of 20.5. Since it runs with diesel combustion it is not prone to knock, while the dual fuel operation that has some of the fuel premixed might have difficulties in running at this high CR. To ensure knock free operation with charging, simulations were performed for different CRs and intake pressures, with excess air ratio 1.5 and combustion duration of $40^{\circ} \mathrm{CA}$. The value of $\lambda=1.5$ is taken as the case with the richest premixed fuel concentration that is expected. Knock Intensity (KI) is calculated with the following formula:

$$
\mathrm{KI}=\mathrm{K}_{1} \cdot\left(1-\mathrm{MFB}_{\mathrm{SOK}}\right)(\mathrm{CR}-1)\left(1-\frac{\alpha_{\mathrm{SOK}}}{\mathrm{K}_{2}}\right)^{\frac{1}{\mathrm{~K}_{3}}} \cdot n
$$

The meaning of every parameter is given in nomenclature. With the increase of excess air ratio, the KI decreases. Figure 11 shows the KI for original CR at two different levels of the Start Of Combustion (SOC): $\mathrm{SOC}=0^{\circ} \mathrm{CA}$ After Top Dead Center (ATDC) and $-2^{\circ} \mathrm{CA}$ ATDC. Calculated KI is larger than zero in all ranges of engine speed and at both levels of start of combustion. This means that CR of 20.5 is not appropriate for dual fuel operation.

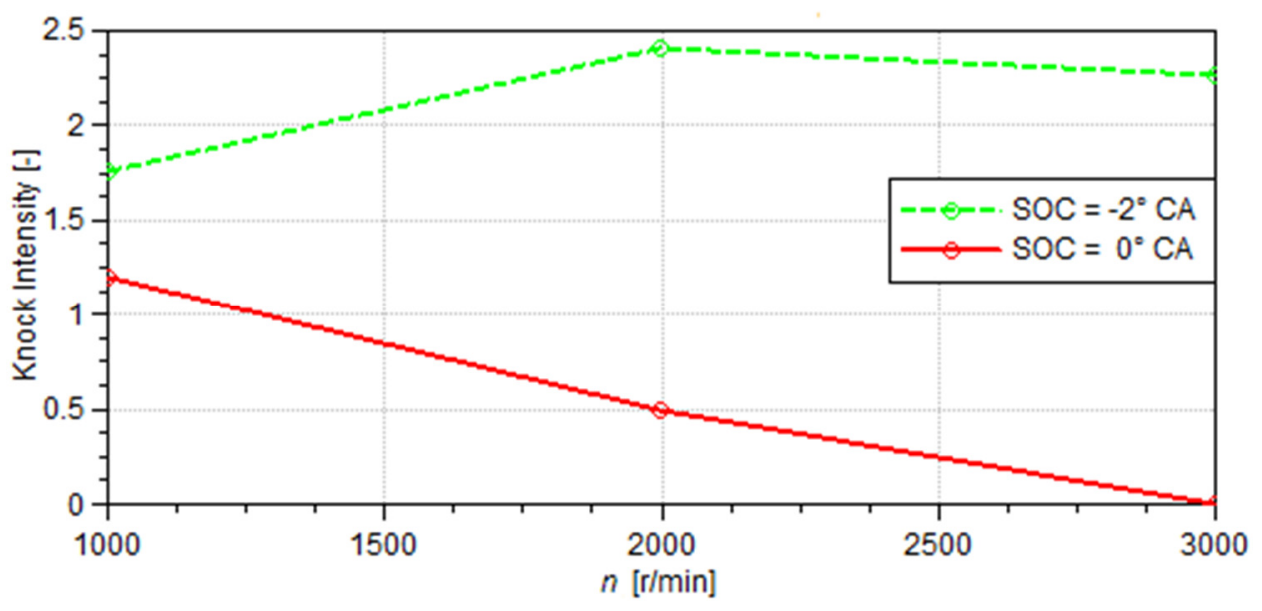

Figure 11. KI, $\mathrm{CR}=20.5, p_{\text {intake }}=1$ bar

In Figures 12-15, similar results for CRs 19, 18, 17 and 16, with ambient intake conditions are given. The simulations were performed for cases with the SOC at the Top Dead Center (TDC) and for the cases with the SOC slightly before TDC. As expected the advanced SOC results in higher KI at all CRs.

The CR of 18 (Figure 13) is the highest CR which allows knock free operation $(\mathrm{KI}=0)$ for $\mathrm{SOC}=0^{\circ} \mathrm{CA}$ at all engine speeds. Advanced $\mathrm{SOC}\left(\mathrm{SOC}=-2^{\circ} \mathrm{CA}\right.$ ATDC) results in knock occurrence at 1,000 r/min while further advancing of SOC results in knock occurrence at all engine speeds.

To test the behaviour of the engine at charged conditions the simulations with $\mathrm{CR}=16$ and $\mathrm{CR}=17$ were performed with $p_{\text {intake }}=2.2$ bar. 


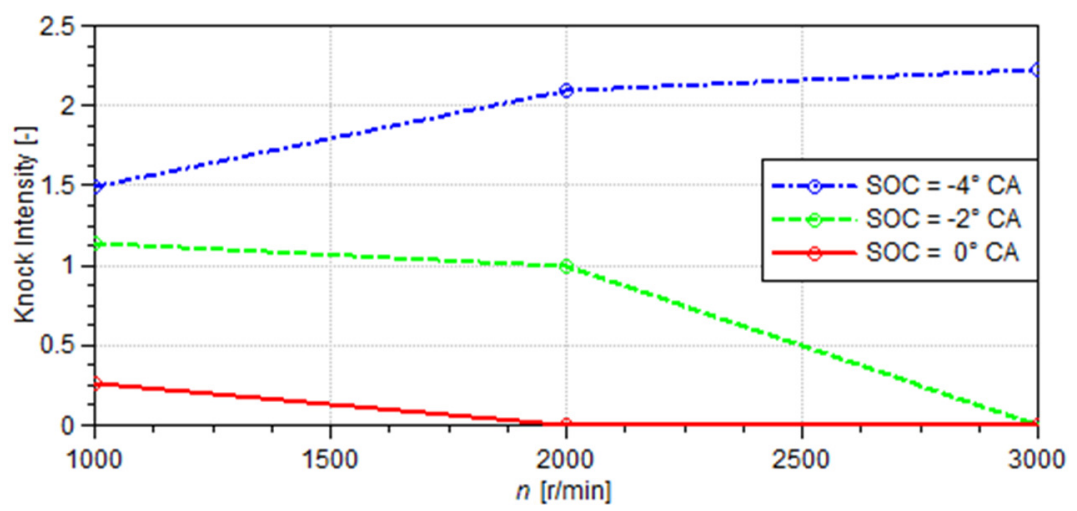

Figure $12 . \mathrm{KI}$ for $\mathrm{CR}=19, p_{\text {intake }}=1 \mathrm{bar}$

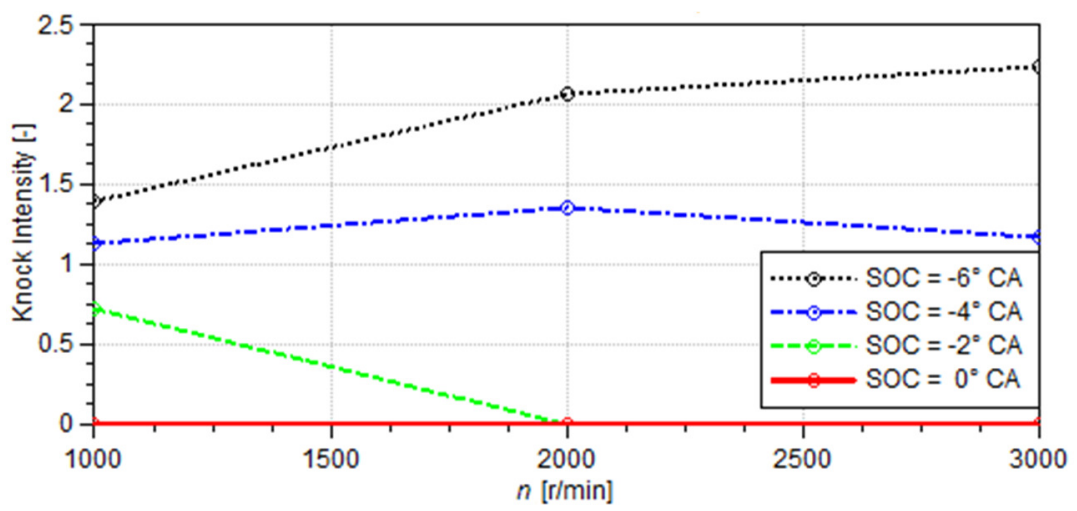

Figure $13 . \mathrm{KI}$ for $\mathrm{CR}=18, p_{\text {intake }}=1 \mathrm{bar}$

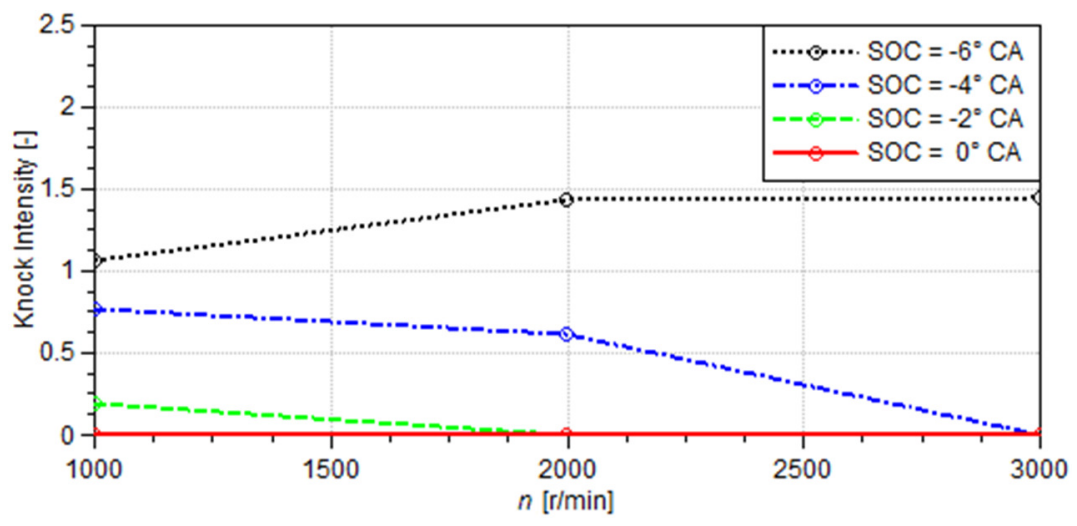

Figure $14 . \mathrm{KI}$ for $\mathrm{CR}=17, p_{\text {intake }}=1 \mathrm{bar}$

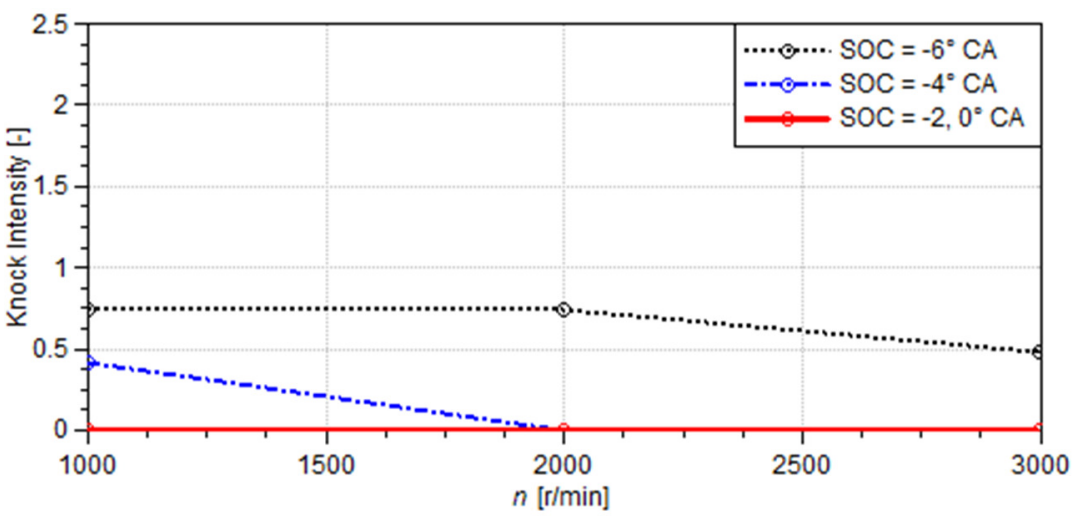

Figure $15 . \mathrm{KI}$ for $\mathrm{CR}=16, p_{\text {intake }}=1 \mathrm{bar}$ 
The results of KI are shown in Figures 16 and 17. Elevated intake pressure increases the KI values compared to the intake pressure of 1 bar. Figure 17 shows KI at 1,000 r/min at both $\mathrm{SOC}$ values $\left(0^{\circ} \mathrm{CA}\right.$ and $\left.-2^{\circ} \mathrm{CA}\right)$. Although $\mathrm{KI}$ at $1,000 \mathrm{r} / \mathrm{min}$ is higher than zero, $\mathrm{CR}$ of 16 might be acceptable because dual fuel engines run with higher air excess ratio $(\lambda)$ at low engine speeds.

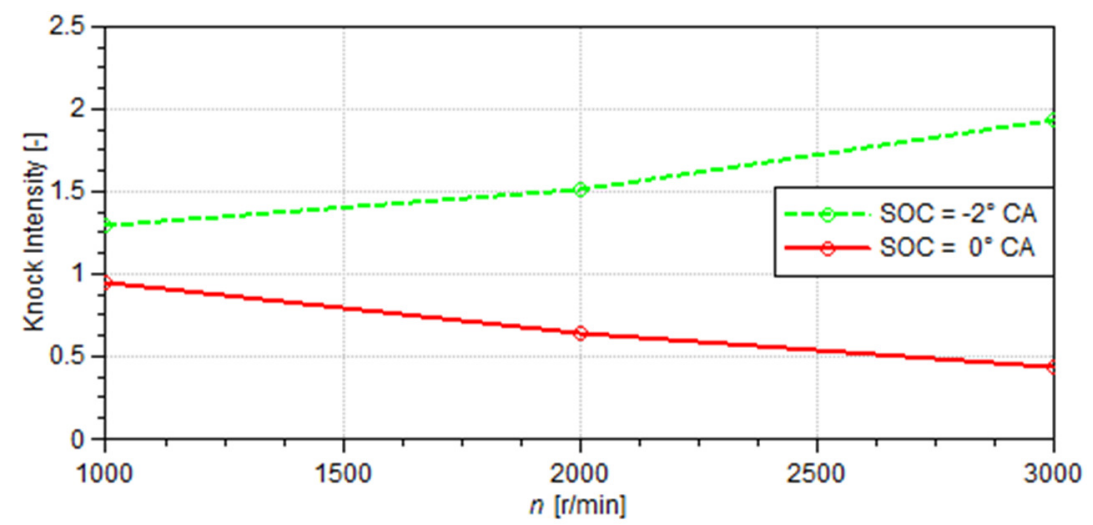

Figure 16. $\mathrm{KI}$ for $\mathrm{CR}=17, p_{\text {intake }}=2.2 \mathrm{bar}$

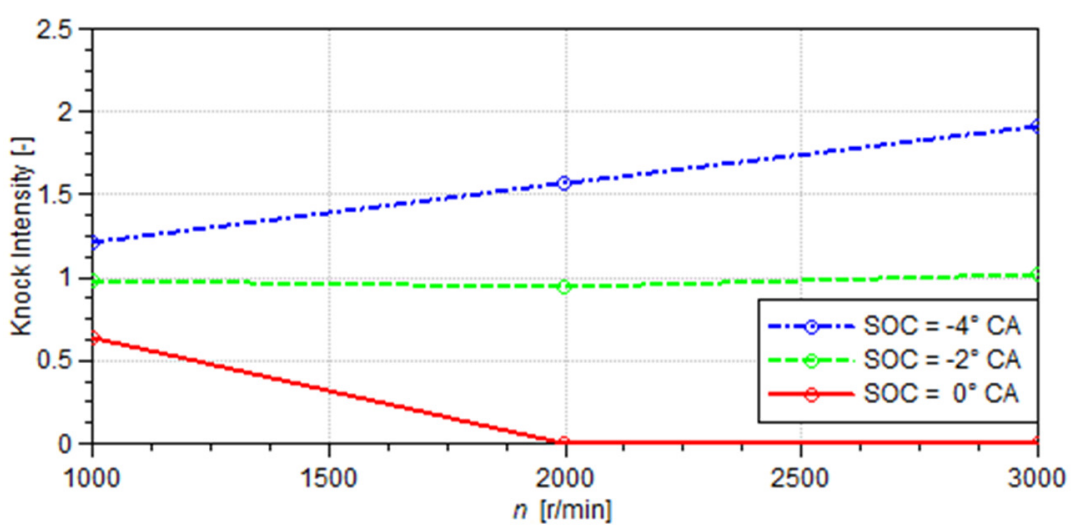

Figure 17. $\mathrm{KI}$ for $\mathrm{CR}=16, p_{\text {intake }}=2.2$ bar

Therefore simulations were repeated with $\lambda$ of 1.8. The results of these simulations are shown in Figure 18, and as can be seen, $\mathrm{KI}$ at 1,000 r/min is still slightly above zero, but it is lower than in the case with $\lambda$ of 1.5 . If the SOC is retarded by $2^{\circ} \mathrm{CA}$, the knock occurrence at $1,000 \mathrm{r} / \mathrm{min}$ disappears. Therefore, to avoid the knock in charged conditions, the SOC has to be after TDC.

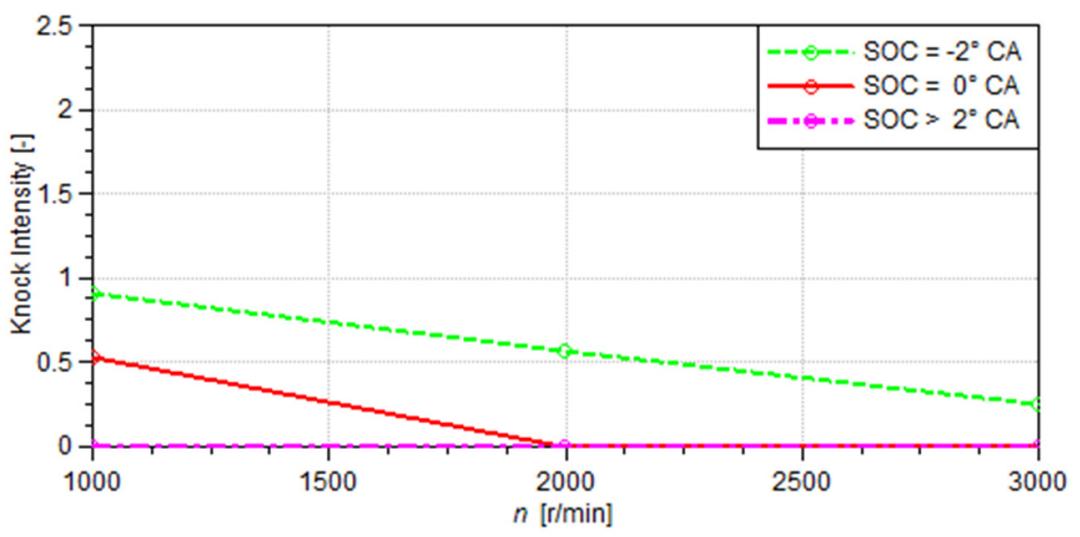

Figure 18. $\mathrm{KI}$ for $\mathrm{CR}=16, p_{\text {intake }}=2.2$ bar, $\lambda=1.8$ 
To test the influence of combustion duration on knock tendency, the combustion duration is also set as a parameter in the simulation model. Results with shortened combustion duration ( $\left.30^{\circ} \mathrm{CA}\right)$ are shown in Figure 19. For shorter combustion duration the KI at the same SOC and engine speed is slightly higher. The case in which $\mathrm{SOC}=4^{\circ} \mathrm{CA}$ ATDC and $\lambda=1.8$ leads to almost completely knock-free operation even at the lowest engine speed.

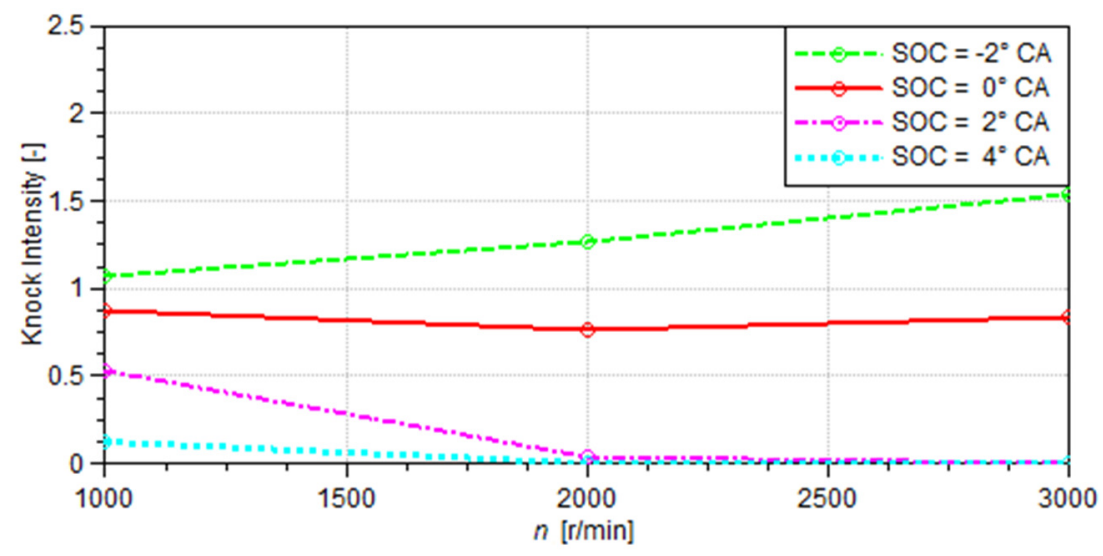

Figure 19. $\mathrm{KI}$ for $\mathrm{CR}=16, p_{\text {intake }}=2.2$ bar, $\lambda=1.8$, combustion duration $=30^{\circ} \mathrm{CA}$

With the additional decrease of CR, knock tendency would be even further reduced. Taking into account the entire range of engine operation and the influence of CR in all other operating conditions, it is deemed that $\mathrm{CR}=16$ is sufficiently low to enable knock-free dual fuel operation. General recommendation for avoiding knock in charged operation is to set the SOC well ATDC and then gradually advance it. In this way the engine operation with reduced risk of damage will be ensured. If the engine is not charged it can be run with the higher CR. The allowed CR depends on the expected intake pressure. In ambient conditions the CR of up to 18 could be tolerated, but in cases with intake pressure above 2 bar, CR should not be higher than 16 .

\section{CONCLUSIONS}

In this study, the effects of injection timing on fuel slip into the exhaust pipe of conventional dual fuel engine (port injected dual fuel converted from conventional diesel engine) due to valve overlap, and the effects of CR on knock occurrence are numerically investigated. The main motivation for this study are questions whether the fuel slip from the cylinder can be reduced by the appropriate injection timing strategy, and what is the CR that allows stable, knock free operation of a conventional dual fuel engine at high load.

The main conclusions of the presented study are:

- The fuel slip from cylinder due to valve overlap is highest at low engine speed $(1,000 \mathrm{r} / \mathrm{min})-0.6 \%$ of the injected fuel slips in the exhaust in the case of naturally aspirated engine and $2.3 \%$ at charged conditions;

- At higher engine speeds (2,000 r/min, 3,000 r/min) fuel slip becomes very low;

- Reduction of fuel slip can be achieved through the optimization of injection timing. Appropriate intermittent injection timing can reduce fuel slip up to 33\% compared to the continuous injection at defined excess air ratio, while inappropriate intermittent injection timing can result in increase of fuel slip up to $62 \%$ in charged conditions;

- Optimized intermittent injection gives benefit on fuel slip, which results in higher thermal efficiency of the engine; 
- When diesel engine is converted into the conventional dual fuel engine, a risk of knock combustion exists, especially in charged intake conditions;

- Besides CR, the knock occurrence depends on the SOC and combustion duration. The advanced SOC increases the knock tendency, while longer combustion duration decreases it;

- In simulated engine the original CR (20.5) is too large for knock free operation, in both ambient and charged intake conditions. CR of 16 allows knock free operation in charged intake conditions, if the SOC is at the TDC or later. Earlier SOC increases the risk of knock occurrence. In the case of ambient intake conditions the engine can operate with CR of up to 18 without the risk of knock, with SOC also at the TDC or later.

\section{ACKNOWLEDGMENT}

The study was performed within the FMENA project "Experimental Research, Optimization and Characterization of piston engine operation with DUal-Fuel COmbustion - DUFCOROC" IP-2014-09-1089 funded by the Croatian Science Foundation. This funding is gratefully appreciated.

\section{NOMENCLATURE}

\begin{tabular}{|c|c|c|}
\hline $\mathrm{K}_{1}$ & constant for definition of overall value of knock integral & {$[\mathrm{min} / \mathrm{r}]$} \\
\hline $\mathrm{K}_{2}$ & $\begin{array}{l}\text { constant for definition of crank angle at which auto ignition } \\
\text { of unburned zone will no longer produce knock }\end{array}$ & [deg] \\
\hline $\mathrm{K}_{3}$ & $\begin{array}{l}\text { constant that defines the influence of unburned mass and } \\
\text { crank angle at start of knock on overall knock intensity } \\
\text { (lower value gives more influence to crank angle) }\end{array}$ & {$[-]$} \\
\hline & engine speed & {$[\mathrm{r} / \mathrm{min}]$} \\
\hline & intake pressure & [bar] \\
\hline & number of revolutions & {$[-]$} \\
\hline
\end{tabular}

\section{Greek letters}

$\alpha_{\mathrm{SOK}} \quad$ crank angle at start of knock

$\lambda \quad$ air excess ratio

\section{Abbreviations}

$\begin{array}{ll}\text { ATDC } & \text { After Top Dead Center } \\ \text { CNG } & \text { Compressed Natural Gas } \\ \text { C } & \text { Cylinder } \\ \text { CA } & \text { Crank Angle } \\ \text { CO } & \text { Carbon Monoxide } \\ \mathrm{CO}_{2} & \text { Carbon Dioxide } \\ \text { CR } & \text { Compression Ratio } \\ \text { EGR } & \text { Exhaust Gas Recirculation } \\ \text { EOI } & \text { End Of Injection } \\ \text { FTDC } & \text { Firing Top Dead Center } \\ \text { HPDI } & \text { High Pressure Direct Injection } \\ \text { IC } & \text { Internal Combustion } \\ \text { ID } & \text { Injection Duration } \\ \text { IVC } & \text { Inlet Valve Closes } \\ \text { IVO } & \text { Inlet Valve Opens } \\ \text { KI } & \text { Knock Intensity } \\ \text { MFB } \text { SOK } & \text { Total Mass Fraction Burned at Start of Knock }\end{array}$




\begin{tabular}{lll}
\hline $\mathrm{MP}$ & Measuring Point & \\
$\mathrm{NO}_{\mathrm{x}}$ & Nitric Oxides & \\
$\mathrm{PL}$ & Plenum & \\
$\mathrm{R}$ & Restriction & \\
$\mathrm{SB}$ & System Boundary & {$\left[{ }^{\circ} \mathrm{CA}\right]$} \\
SOC & Start Of Combustion & {$\left[{ }^{\circ} \mathrm{CA}\right]$} \\
SOI & Start Of Injection & \\
TDC & Top Dead Center & \\
UHC & Unburned Hydrocarbons
\end{tabular}

\section{REFERENCES}

1. Konigsson, F., Advancing the Limits of Dual Fuel Combustion, Licenciate Thesis, Royal Institute of Technology Stockholm, Stockholm, Sweden, 2012.

2. Serrano, D. and Bertrand, L., Exploring the Potential of Dual Fuel Diesel-CNG Combustion for Passenger Car Engine, Proceedings of the FISITA 2012 World Congress, Beijing, China, 2012.

3. Dahodwala, M., Joshi, S., Koehler, E. and Franke, M., Investigation of Diesel and CNG Combustion in a Dual Fuel Regime and as an Enabler to Achieve RCCI Combustion, SAE Technical Paper 2014-01-1308, 2014, https://doi.org/10.4271/2014-01-1308

4. Shah, A., Thipse, S. S., Tyagi, A., Rairikar, S. D., Kavthekar, K. P. and Marathe, N. V., Literature Review and Simulation of Dual Fuel Diesel-CNG Engines, SAE International, Symposium on International Automotive Tehnology, 2011-26-0001, Pune, Maharashtra, India, 2011.

5. Lounici, M. S., Loubar, K., Tarabet, L., Balistrou, M., Niculescu, D. C. and Tazerout, M., Towards Improvement of Natural Gas-diesel Dual Fuel Mode: An Experimental Investigation on Performance and Exhaust Emission, Energy, Vol. 64, pp 200-211, 2014, https://doi.org/10.1016/j.energy.2013.10.091

6. Mustafi, N. N., Raine, R. R. and Verhelst, S., Combustion and Emission Characteristics of a Dual Fuel Engine Operated on Alternative Gaseous Fuels, Fuel, Vol. 109, pp 669-678, 2013, https://doi.org/10.1016/j.fuel.2013.03.007

7. Abd Alla, G. H., Soliman, H. A., Badr, O. A. and Abd Rabbo, M. F., Effect of Pilot Fuel Quantity on the Performance of a Dual Fuel Engine, Energy Conversion \& Management, Vol. 41, No. 6, pp 559-572, 2000, https://doi.org/10.1016/S0196-8904(99)00124-7

8. Selim, M. Y. E., Pressure-time Characteristics in Diesel Engine Fuelled with Natural Gas, Renewable Energy, Vol. 22, No. 4, pp 473-489, 2001, https://doi.org/10.1016/S0960-1481(00)00115-4

9. Papagiannakis, R. G. and Hountalas, D. T., Combustion and Exhaust Emission Characteristics of a Dual Fuel Compression Ignition Engine Operated with Pilot Diesel Fuel and Natural Gas, Energy Conversion and Management, Vol. 45, No. 18-19, pp 2971-2987, 2004, https://doi.org/10.1016/j.enconman.2004.01.013

10.Cameretti, M. C., Ciaravola, U., Tuccillo, R., De Simio, L. and Iannaccone, S., A Numerical and Experimental Study of Dual Fuel Diesel Engine for Different Injection Timings, Applied Thermal Engineering, Vol. 101, pp 630-638, 2016, https://doi.org/10.1016/j.applthermaleng.2015.12.071

11.Scott Guerry, E., Mostafa, S. R., Kalyan, K. S., Sundar, R. K. and Sohail, A., Injection Timing Effects on Partially Premixed Diesel-methane Dual Fuel Low Temperature Combustion, Applied Energy, Vol. 162, pp 99-113, ISSN 0306-2619, 2016, https://doi.org/10.1016/j.apenergy.2015.10.085

12.Kozarac, D., Tomic, R., Taritas, I., Chen, J. and Dibble, R., A Model for Prediction of Knock in the Cycle Simulation by Detail Characterization of Fuel and Temperature Stratification, SAE Int. J. Engines, Vol. 8, No. 4, pp 1520-1534, 2015, https://doi.org/10.4271/2015-01-1245 
13.Kozarac, D., Schuemie, A., Ofner, H. and Tatschl, R., Modeling of Natural Gas Engine with the Emphasis on Prediction of Knock Presented at $6^{\text {th }}$ European Congress on Computational Methods in Applied Sciences and Engineering (ECCOMAS 2012), Vienna, Austria, September 10-14, 2012.

14.Sjeric, M., Taritas, I., Tomic, R., Blazic, M., Kozarac, D. and Lulic, Z., Efficiency Improvement of a Spark-ignition Engine at Full Load Conditions using Exhaust Gas Recirculation and Variable Geometry Turbocharger - Numerical Study, Energy Conversion and Management, Vol. 125, pp 26-39, 2016, ISSN 0196-8904, https://doi.org/10.1016/j.enconman.2016.02.047 